\title{
Multiplex PCR Assay for Simultaneous Detection of Korean Quarantine Phytoplasmas
}

\author{
Young-Hwan Kim ${ }^{1}$, Nang Kyu Win ${ }^{1}$, Chang-Gi Back ${ }^{1}$, Mi-Chi Yea ${ }^{1,2}$, Kyu-Ock Yim ${ }^{2}$ and Hee-Young Jung ${ }^{1 *}$ \\ ${ }^{I}$ School of Applied Bioscience, Kyungpook National University, Daegu 702-701, Korea \\ ${ }^{2}$ Animal, Plant and Fisheries Quarantine and Inspection Agency, Anyang 430-757, Korea
}

(Received on August 23, 2011; Revised on October 16, 2011; Accepted on October 17, 2011)

\begin{abstract}
Multiplex PCR assays were developed for the simultaneous detection of ten important Korean quarantine phytoplasmas. The species-specific primers were designed based on ribosomal protein, putative preprotein translocase $Y$, immunodominant protein, elongation factor $\mathrm{TU}$, chaperonin protein and the $16 \mathrm{~S}$ rRNA genes of 'Candidatus (Ca.) Phytoplasma' species. Three main primer sets were prepared from ten designed primer pairs to limit nonspecific amplification as much as possible. The multiplex PCR assay using the three primer sets successfully amplified the correct conserved genes for each ' $\mathrm{Ca}$. Phytoplasma' species. In addition, ten important ' $\mathrm{C} a$. Phytoplasma' species could be easily determined by recognizing band patterns specific for each phytoplasma species from three primer sets. Moreover, a high sensitivity of multiplex PCR for each primer set was observed for samples containing a low DNA concentration $(10 \mathrm{ng} / \mu \mathrm{l})$. This study provides the useful multiplex PCR assay as a convenient method to detect the presence of ten important quarantine phytoplasmas in Korea.
\end{abstract}

Keywords : 'Candidatus Phytoplasma' species, Detection, Multiplex PCR, Quarantine

Phytoplasma associated plant diseases occur in many crops worldwide and more than 300 distinct plant diseases have been attributed to phytoplasmas, affecting hundreds of plant genera (Hoshi et al., 2007). Phytoplasmas severely affect herbaceous and woody plants and are the primary limiting factors for many important crops all over the world. Many of the most important diseases from an economic standpoint are those affecting woody plants, including coconut lethal yellowing, peach X-disease, grapevine yellows and apple proliferation, and those affecting herbaceous plants, including vegetable crops, ornamental plants and legumes (Bertaccini and Duduk, 2009). Because of these diseases,

\footnotetext{
*Corresponding author.

Phone) +82-53-950-5760, FAX) +82-53-950-6758

E-mail)heeyoung@knu.ac.kr
}

the movement of the affected plant species should be internationally restricted through quarantine regulations (Lee et al., 2000).

In Korea, phytoplasma related diseases have been reported in about 50 different plant species and the phytoplasmas were found to be associated with 6 'Candidatus $(\mathrm{Ca}$.) Phytoplasma (P.)' species including 'Ca. P. asteris', ' $C a$. P. pruni', 'Ca. P. trifolii', 'Ca. P. solani', 'Ca. P. castaneae' and ' $\mathrm{Ca}$. P. ziziphi'. Among them, 'Candidatus Phytoplasma asteris' associated plant diseases were found to affect the widest range of plants (Lee et al., 2004). The Korea National Plant Quarantine Services (NPQS) listed 20 phytoplasma diseases that should be prohibited and regulated including apple proliferation, strawberry witches' broom, walnut witches' broom, etc. Those diseases were associated with 10 important ' $C a$. Phytoplasma' species and among them; ' $\mathrm{Ca}$. P. asteris' associated plant diseases were reported to be present in 54 plant families of 350 plant species (http://www.nqps.go.kr). Nowadays, molecular based identification has been widely used to quickly detect pathogens. Nested PCR following PCR primed by phytoplasma-universal primers are commonly used in phytoplasma detection in Korea. Generally, identification of an unknown phytoplasma species from one disease requires a significant amount of time. After PCR analyses, sequencing or restriction fragment length polymorphism analyses are needed to further differentiate pathogen at the phytoplasma species level. Thus, quick and efficient detection methods for ten important phytoplasma species are needed in regards to quarantine services. Simultaneous detection of two or more DNA targets can be achieved by duplex or multiplex PCR in a single reaction by adding several specific primers into the PCR cocktail. López et al. (2006) demonstrated that the multiplex PCR is a valuable tool for detection and identification purposes in plant pathology because more than one pathogen frequently infect a single crop or host. Therefore, in this study, we developed a multiplex PCR assay by designing phytoplasma speciesspecific primer pairs based on various conserved genes including $16 \mathrm{~S}$ rRNA, ribosomal protein gene operon $(r p)$, 
Table 1. Phytoplasma strains of the related 'Candidatus Phytoplasma' species used in this study

\begin{tabular}{|c|c|c|c|}
\hline Strain & Associated disease & Related ' $\mathrm{Ca}$. Phytoplasma' species & Geographic origin \\
\hline OY-M & Onion yellows phytoplasma mild strain & 'Ca. P. asteris' & Japan $^{\mathrm{a}}$ \\
\hline WX & Peach X-disease phytoplasma & 'Ca. P. pruni'* & USA \\
\hline $\mathrm{AP}$ & Apple proliferation phytoplasma & 'Ca. P. mali' & Germany \\
\hline LY & Coconut lethal yellowing phytoplasma & 'Ca. P. palmae' & Florida, $\mathrm{USA}^{\mathrm{b}}$ \\
\hline ULW & Elm witches' broom phytoplasma & 'Ca. P. ulmi' & France $^{c}$ \\
\hline FD & Grapevine flavescence dorée phytoplasma & 'Ca. P. vitis'* & Italy $^{\mathrm{c}}$ \\
\hline PD & Pear decline phytoplasma & 'Ca. P. pyri' & Germany \\
\hline ESFY & European stone fruit yellows phytoplasma & 'Ca. P. prunorum' & Germany \\
\hline RYD & Rice yellow dwarf phytoplasma & 'Ca. P. oryzae' & Japan $^{\mathrm{a}}$ \\
\hline STOL & Pepper stolbur phytoplasma & 'Ca. P. solani'* & Serbia $^{c}$ \\
\hline
\end{tabular}

*Samples were provided as purified DNA and the sources are given.

These Candidatus names were proposed to IRPCM but have not yet been officially published.

${ }^{a}$ S. Namba, University of Tokyo, Japan; ${ }^{b}$ N.A. Harrison, University of Florida, USA; ${ }^{\mathrm{c}}$ A. Bertaccini, University of Bologna, Italy. Other samples were collected by K.O. Yim, National Plant Quarantine Service, South Korea.

elongation factor TU (tuf), putative preprotein translocase $\mathrm{Y}(\mathrm{sec} \mathrm{Y})$, immunodominant protein $(\mathrm{idp})$ and chaperonin protein (groEL) genes to simultaneously detect ten important phytoplasmas.

The phytoplasmas used in this study are listed in Table 1. DNA preparations from plants infected by 10 'Candidatus Phytoplasma' species were obtained from other researchers and were maintained as DNA templates at $-80{ }^{\circ} \mathrm{C}$ at Laboratory of Plant Pathology, Kyungpook National University, Korea. To design phytoplasma species-specific primers, all available published DNA sequences data of $16 \mathrm{~S}$ rRNA genes, groEL genes, idp genes, tuf genes, $r p$ genes and sec $\mathrm{Y}$ genes of the same 10 phytoplasma species were retrieved from the NCBI database, and aligned with available sequences for each phytoplasma species. On the basis of all these aligned each gene sequence, the conserved regions of the sequences for specific phytoplasma species were selected and searched against the NCBI database. Then, the most stable gene for each phytoplasma species was selected to design species-specific primers (Table 2) and used for PCR. Each designed primer pair was tested by PCR analysis with the target DNA template of ' $\mathrm{Ca}$. Phytoplasma' species and the resulted PCR fragment was sequenced. The designed primers were successfully primed the sequences from groEL, idp, tuf, rp, sec Y and 16S rRNA genes. By the use of ten primer pairs in the multiplex PCR assay at the same time, nonspecific amplification was observed for some phytoplasma species. Therefore, the ten primer pairs were separated into smaller sets by matching all possible combinations, and various PCR conditions were tested to limit dimer formation and nonspecific amplification as much as possible. Finally, three main primer sets were developed for the ten ' $\mathrm{Ca}$. Phytoplasma' species and the primer set $\mathrm{A}$ is for ' $\mathrm{Ca}$. P. asteris', ' $\mathrm{Ca}$. $\mathrm{P}$. prunorum', 'Ca. P. mali' and 'Ca. P. pruni'; set B for 'Ca. P. solani', 'Ca. P. pyri', 'Ca. P. oryzae' and 'Ca. P. vitis'; and set C for 'Ca. P. palmae' and 'Ca. P. ulmi' (Table 2).

Among the tested various PCR conditions for all three primer sets, the best conditions were $94{ }^{\circ} \mathrm{C}$ for $1 \mathrm{~min}$ followed by 35 cycles of $94^{\circ} \mathrm{C}$ for $30 \mathrm{~s}, 53^{\circ} \mathrm{C}$ for $30 \mathrm{~s}$ and $72{ }^{\circ} \mathrm{C}$ for $90 \mathrm{~s}$ and a final extension step of $72^{\circ} \mathrm{C}$ for $7 \mathrm{~min}$. The amplification reaction was performed by multiplex PCR with 4 primer pairs, for instance, primer set A included $\mathrm{Ca}$. P. asteris-groEL-1/Ca. P. asteris-groEL-9, Ca. P. prunorum-idp-F/Ca. P. prunorum-idp-R, Ca. P. mali-tufF/Ca. P. mali-tuf-R and Ca. P. pruni-rp-F/Ca. P. pruni-rp-R; $1 \mu \mathrm{l}$ each (10 pM), $2 \mu \mathrm{l}$ of 10X PCR buffer, $2 \mu \mathrm{l}$ of dNTPs mixture (10 mM, each dNTP $2.5 \mathrm{mM}), 1 \mathrm{U}$ of Taq DNA polymerase and $50 \mathrm{ng}$ DNA in a final volume of $20 \mu \mathrm{l}$. The amplified PCR products were separated on a $2 \%$ agarose gels in 1X TAE buffer (4.84 g Tris, $1.14 \mathrm{ml}$ Acetic acid, 2.0 ml $0.5 \mathrm{M}$ EDTA, $1,000 \mathrm{ml}$ distilled water) containing ethidium bromide and visualized under UV light.

The phytoplasma species-specific primer sets were evaluated in the multiplex PCR assay. Using the primer set A, the 330 bp DNA fragment of the groEL gene of ' $\mathrm{Ca}$. P. asteris', the 170 bp DNA fragment of the idp gene of ' $\mathrm{Ca}$. P. prunorum', the $750 \mathrm{bp}$ DNA fragment of tuf gene of ' $\mathrm{Ca}$. $\mathrm{P}$. mali' and the 1,070 bp DNA fragment of the $r p$ gene of 'Ca. P. pruni' were expected to be amplified by PCR. The target gene fragment for ' $\mathrm{Ca}$. Phytoplasma' species was successfully amplified as shown in Fig. 1. The expected size of PCR product generated with each primer pair is shown in Table 2. The other two primer sets also amplified the correct size fragment (Fig. 1). The three designed primer sets in multiplex PCR can be used to detect ten ' $\mathrm{Ca}$. Phytoplasma' species at the same time.

However, this experiment was done with the use of 
Table 2. Ten 'Candidatus Phytoplasma' species-specific primer pairs and the three prepared primer sets used in multiplex PCR assay

\begin{tabular}{|c|c|c|c|}
\hline Primer name & Oligonucleotide sequence $\left(5^{\prime} \rightarrow 3^{\prime}\right)$ & $\begin{array}{c}\text { Approximate } \\
\text { product size (bp) }\end{array}$ & Primer set \\
\hline Ca. P. asteris-groEL-1 & Forward- GGT GGA AAA GCT TTA GTT G & 330 & \multirow{8}{*}{ Set A } \\
\hline Ca. P. asteris-groEL-9 & Reverse- GGC TGC TGT GGT AAG TTT GA & & \\
\hline Ca. P. prunorum-idp-F & Forward- CAA ATT CAT TAG GAG AAA ATG TTT & 170 & \\
\hline Ca. P. prunorum-idp-R & Reverse- CCA AGC AAA AGA ATC ATT AGG & & \\
\hline Ca. P. mali-tuf-F & Forward- CGT GAA CAT GTT TTG TTA GCT G & 750 & \\
\hline Ca. P. mali-tuf-R & Reverse- TTG AAT TAA ATC ATC CAA TCG CT & \multirow{3}{*}{1,070} & \\
\hline Ca. P. pruni-rp-F & Forward- GCT ATT GCA AAT CAG ATG TCT GT & & \\
\hline Ca. P. pruni-rp-R & Reverse- CGA AGA TAC TAG AAA ATT ATT AGT & & \\
\hline Ca. P. solani-tuf-F & Forward- CGC AGA TAG TGT TAT GCC TC & 990 & \multirow{8}{*}{ Set B } \\
\hline Ca. P. solani-tuf-R & Reverse- GTT AGC CAA ACC AGG TTC TGT G & & \\
\hline Ca. P. pyri-rp-F & Forward- GTA AAA AAA GTA TCA ATT ACA CCT C & 750 & \\
\hline Ca. P. pyri-rp-R & Reverse- CAA TGG CTG AAC AAT TAG AAC & & \\
\hline Ca. P. oryzae-16S-F & Forward- AAC TGG ATA GGA AAT TAA AAG GT & 570 & \\
\hline Ca. P. oryzae-16S-R & Reverse- ATG AGA CTG CCA ATA & \multirow{3}{*}{380} & \\
\hline Ca. P. vitis-tuf-F & Forward- GAA CAT GAT CGC AGG AGC TT & & \\
\hline Ca. P. vitis-tuf-R & Reverse- AAC GTA AAA GGT AGA GGA ACT & & \\
\hline Ca. P. palmae-rp-F & Forward- AGG AAA GGC AAT TAA AG & 1,020 & \multirow{4}{*}{ Set $\mathrm{C}$} \\
\hline Ca. P. palmae-rp-R & Reverse- GGT GAC AAA GGT GAC AAA AT & \multirow{3}{*}{470} & \\
\hline Ca. P. ulmi-secY-F & Forward- GCG TTT GAT CCA ATG TT & & \\
\hline Ca. P. ulmi-secY-R & Reverse- GCA AAT GGT TCG GAA AC & & \\
\hline
\end{tabular}

known phytoplasma DNA templates in PCR analysis using the designed primer sets. Therefore, second experiment was further carried out in order to know if the designed primer sets work when one DNA temple of a known phytoplasma species is used in multiplex PCR. The results of second experiments were shown in Fig. 2. The three primer sets amplified only one specific target gene fragment from ' $\mathrm{Ca}$.

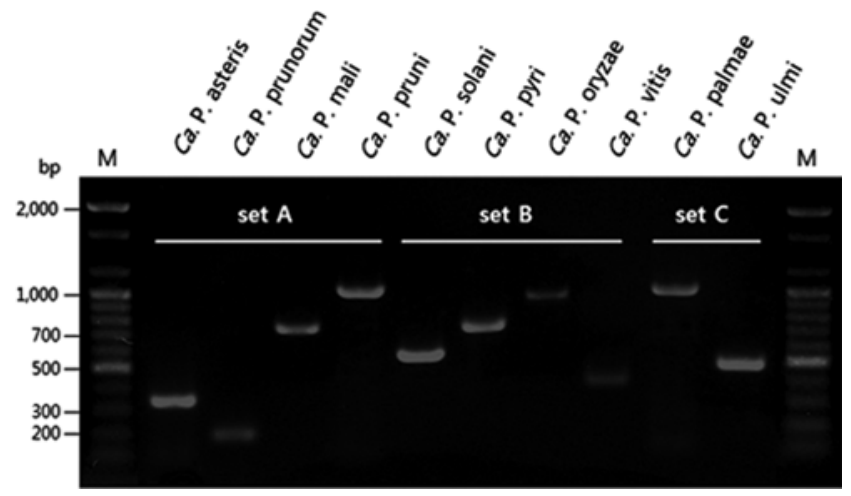

Fig. 1. Agarose gel electrophoresis of multiplex polymerase chain reaction (PCR) products from total DNA samples of each of 10 ' $\mathrm{Ca}$. Phytoplasma' species using 3 sets of primers (Set A, B and C). The size of amplified PCR product for each ' $\mathrm{Ca}$. Phytoplasma' species of 3 primer sets is described in Table 2. A 4 $\mu \mathrm{l}$ sample from a total of $20 \mu \mathrm{l}$ of each reaction mixture was run on a $2.0 \%$ agarose gel. Lane M: 100 bp plus DNA ladder.
P. mali', 'Ca. P. pruni', 'Ca. P. prunorum', 'Ca. P. solani' and ' $\mathrm{Ca}$. P. vitis', with correct sizes. However, for the other five phytoplasma species, the primer sets amplified additional PCR products of different sizes. For instance, there were not only the amplified DNA fragment of ' $\mathrm{Ca}$. P. asteris' by the primer set A but also nonspecific amplified fragments ( $\sim 600 \mathrm{bp}$ and $\sim 900 \mathrm{bp}$ ) were found in primer sets $\mathrm{B}$ and $\mathrm{C}$ (Fig. 2). Under these conditions, it would be difficult to identify the bands corresponding to unknown phytoplasma. In this case, we need to consider which phytoplasma species can be detected by each of primer set, and to recognize the band size of each phytoplasma species. To solve this problem, the amplified band size ( $\sim 900 \mathrm{bp})$ in primer set $\mathrm{C}$ can be neglected because the fragment amplified by primer set $\mathrm{C}$ are $1,020 \mathrm{bp}$ long and $470 \mathrm{bp}$ band is from ' $\mathrm{Ca}$. P. palmae' and ' $\mathrm{Ca}$. P. ulmi'. Also, the amplified fragment ( $\sim 00 \mathrm{bp})$ by primer set $\mathrm{B}$ can be neglected because there will be only one band if the unknown phytoplasma is ' $\mathrm{Ca}$. P. solani'. Similarly, we can differentiate these two phytoplasmas (' $\mathrm{Ca}$. P. asteris' or ' $C a$. P. solani') when nonspecific amplification are appeared. Therefore, the best way to address this issue is to recognize the specific band patterns for each phytoplasma species and identify the unknown phytoplasma species based on the band patterns. This phenomenon was consistent with a previous report, where the amplification of 


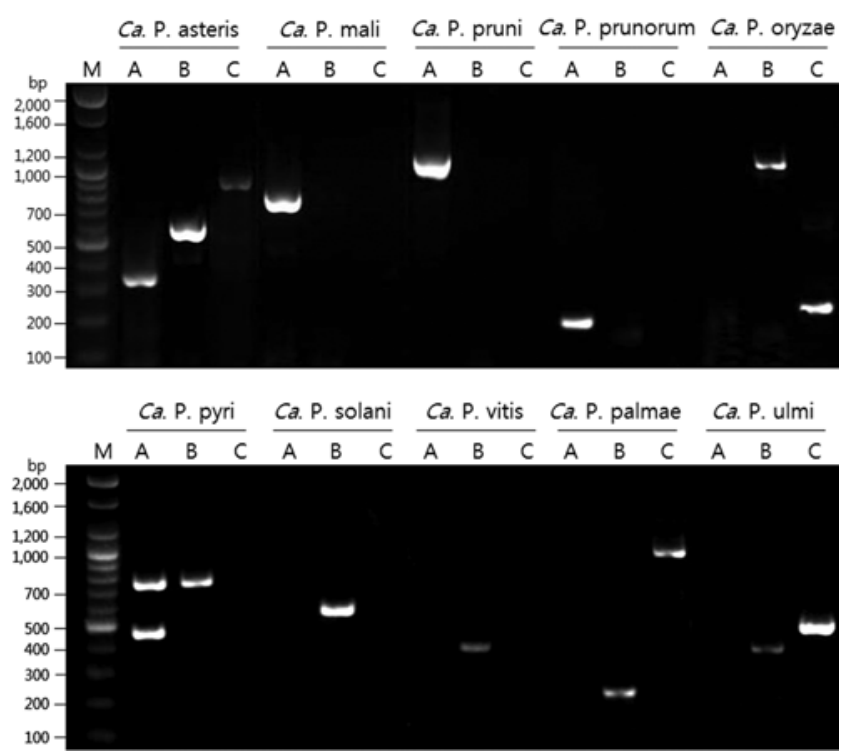

Fig. 2. Agarose gel electrophoresis of multiplex PCR products showing specific amplified DNA fragment patterns obtained from each ' $\mathrm{Ca}$. Phytoplasma' species by using 3 primer sets. Electrophoresis was done as in Fig. 1. Lane M: 100 bp plus DNA ladder; A: set A; B: set B; and C: set C.

additional non-target DNA products was observed in the tested samples including uninfected plant controls (Hodgetts et al., 2008). Next, the sensitivity of multiplex PCR using the primer sets was also determined. The concentration of total DNA templates was diluted from $50 \mathrm{ng} / \mu \mathrm{l}$ to $10 \mathrm{ng} / \mu \mathrm{l}$. Positive reactions were observed at DNA concentrations of $10 \mathrm{ng} / \mu \mathrm{l}$ (Fig. 3). Therefore, the primer sets can detect ten phytoplasma species even in plant samples containing low DNA concentrations of the phytoplasma.

Multiplex PCR assays were developed because they are less time-consuming and require fewer steps to completion

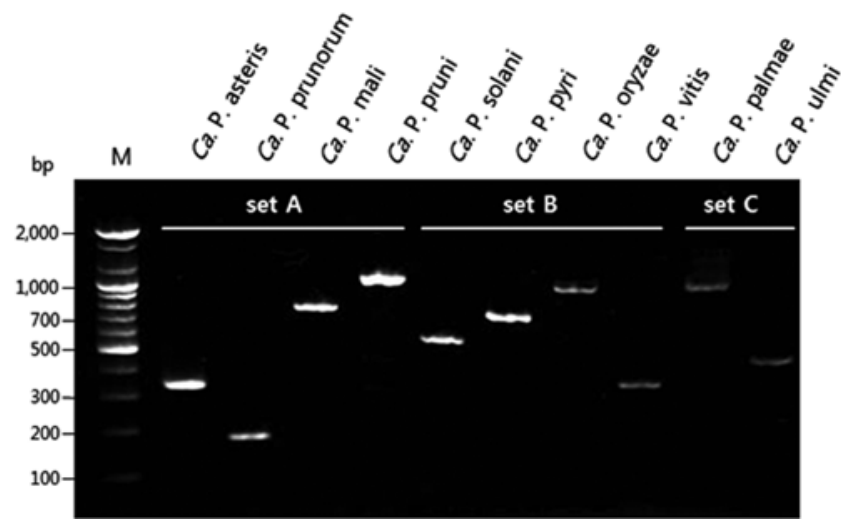

Fig. 3. Agarose gel electrophoresis of multiplex PCR products from $10 \mathrm{ng} \mu \mathrm{l}^{-1}$ of total DNA concentration of each ' $\mathrm{Ca}$. Phytoplasma' species using 3 sets of primers (Set A, B and C). Electrophoresis was done as in Fig. 1. Lane M: 100 bp plus DNA ladder.
(Clair et al., 2003; Edwards and Gibbs, 1994). In addition, this approach was used by other research groups to differentiate group-specific phytoplasmas. Daire et al. (1997) designed two primer pairs, FD9f/r and STOL11f2/r1, and used in multiplex PCR to detect EY-group phytoplasma or stoulbur-subgroup phytoplasmas. To differentiate aster yellows phytoplasma strains, Elateek (2010) developed a multiplex PCR assay for plant samples and leafhopper. Most multiplex PCR assays have been used to identify phytoplasma specific groups, but species-specific primers for ' $C a$. Phytoplasma' have not been reported. This is the first time that a multiplex PCR assay was developed using species-specific primer sets to detect ten important ' $\mathrm{Ca}$. Phytoplasma' species. In addition, molecular markers such as groEL- and idp genes-based primers were shown to be reliable in the phytoplasma differentiation. These multiplex PCR assays make it possible to detect and differentiate ten important ' $\mathrm{Ca}$. Phytoplasma' species, which are of quarantine importance in Korea, without the need for conducting multiple PCR and sequencing of the PCR products.

\section{Acknowledgements}

The authors would like to thank N.A. Harrison, A. Bertaccini and S. Namba for providing phytoplasma strains. This work was supported by grant from the National Plant Quarantine Service of Korea and Mid-career Researcher Program through NRF grant funded by the MEST (No. 2010-0027638).

\section{References}

Bertaccini, A. 2007. Phytoplasmas: diversity, taxonomy, and epidemiology. Front. Biosci. 12:673-689.

Bertaccini, A. and Duduk, B. 2009. Phytoplasma and phytoplasma diseases: a review of recent research. Phytopathol. Mediterr. 48:355-378.

Clair, D., Larrue, J., Aubert, G., Gillet, J., Cloquemin, G. and Boudon-Padieu, E. 2003. A multiplex nested-PCR assay for sensitive and simultaneous detection and direct identification of phytoplasma in the Elm yellows group and Stolbur group and its use in survey of grapevine yellows in France. Vitis 42:151157.

Daire, X., Clair, D., Reinert, S. W. and Boudon-Padieu, E. 1997. Detection and differentiation of grapevine yellows phytoplasmas belonging to the elm yellows group and to the stolbur subgroup by PCR amplification of non-ribosomal DNA. Eur. J. Plant Pathol. 103:507-514.

Edwards, M. C. and Gibbs, R. A. 1994. Multiplex PCR: advantages, development, and applications. Genome Res. 3:S65$\mathrm{S} 75$.

Elateek, S. 2010. Molecular and biochemical genetic studies on some leafhopper transmitted plant pathogens. Ph.D Thesis. 
The Ohio State University, Wooster, USA.

Firrao, G., Garcia-Chapa, M. and Marzachì, C. 2007. Phytoplasmas: genetics, diagnosis and relationships with the plant and insect host. Front. Biosci. 12:1353-1375.

Hodgetts, J., Boonham, N., Mumford, R., Harrison, N. and Dickinson, M. 2008. Phytoplasma phylogenetics based on analysis of secA and 23S rRNA gene sequences for improved resolution of candidate species of 'Candidatus Phytoplasma'. Int. J. Syst. Evol. Microbiol. 58:1826-1837.

Hoshi, A., Oshima, K., Kakizawa, S., Oshima, K. and Namba, S. 2007. Host-parasite interaction of phytoplasmas from a molecular biological perspective. Bull. Insectol. 60:105-107.

Lee, I.-M., Davis, R. E. and Gundersen-Rindal, D. E. 2000. Phytoplasma: ecology and genomic diversity. Phytopathology 88:1359-1366.

López, M. M., Bertolini, E., Marco-Noales, E., Llop, P. and Cambra, M. 2006. Update on molecular tools for detection of plant pathogenic bacteria and viruses. In: Molecular diagnostics: current technology and applications, ed. by J.R. Rao, C.C. Fleming, and J.E. Moore, pp.1-46. Horizon Bioscience, Wymondham, UK.

Thompson, J. D., Higgins, D. G. and Gibson, T. J. 1994. CLUSTAL $\mathrm{W}$ : improving the sensitivity of progressive multiple sequence alignment through sequence weighting, position-specific gap penalties and weight matrix choice, Nucleic Acids Res. 22:4673-4680.

Torres, E., Bertolini, E., Cambra, M., Monton, C. and Martin, M. P. 2005. Real-time PCR for simultaneous and quantitative detection of quarantine phytoplasmas from apple proliferation (16SrX) group. Mol. Cell. Probes 19:334-340.

Zhang, J., Hogenhout, S. A., Nault, L. R., Hoy, C. W. and Miller, S. A. 2004. Molecular and symptom analyses of phytoplasma strains from lettuce reveal a diverse population. Phytopathology $94: 842-849$. 